\title{
Why Has Manufacturing Employment Declined?
}

\author{
John A. Tatom
}

NITED STATES manufacturing employment grew litte in 1986. Currently at about 19 million workers, it is below the 21 million employed at its peak in 1979. This disappointing performance often is attributed to the declining international competitiveness of U.S. manufacturing. Such argtments, however, are tenuous at best: U.S. manufacturing output expanded note rapidly during the period of dollar appreciation from 1980-84 than in had over the previous four years when the dolkar's value was falling. More importantly, the growth of manufacturing abroad has been anemic during this decade. A variety of output, cost and productivity measures reveal that the competiliveness of U.S. manufacturing has actually improved.'

Concem over the recent perfomance of manufacturing employment, however, is not so easily rebutted. Indeed, viewed alongside the strength of U.S. manufacturing output growth, there seems to be a "JekylHyde" quality to the e s. manulacturing sector performance. A longer-run pespective on manulacturing employment and an understanding of economic forces contributing to it, however, reveals that the recent dedine is not unusual and simply reflects the

John A. Tatom is an assistant vice president at the Federal Reserve Bank of St. Louis. Michael L. Durbin provided research assistance.

'See Tatom (1986). Clark (1986) has pointed to the unusual strength of manufacturing output in recent years.

2See Clark (1986). strength of U.S. manufacturing productivity growth in the 1980s.

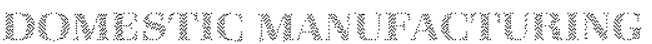

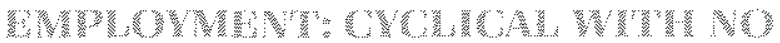 委}

Chart 1 shows manufacturing employment and oulput 1982 pricesi since 1948 . As one can see by examin" ing the shaded periods of business recession, both manufacturing employment and manufacturing out put are strongly cyclical. What is equally evident is that manufacturing employment has shown little tendency to grow over the prior three decades, except for its shapp rise from 1960 to 1967 . Indeed, at its peak in 1979, there were fewet than one million more workers in the manufacturing sector than in mid-1969, and only about four million more workers than in 1956 and eaty 1957. Thus, temporaty negative growth in man ufacturing employment is neither umprecedented, no: should it be assessed relative to a presumption that manufacturing employment has exhibited any significant growth since 1948 .

The cyclical explanation, however, does not fully account for the decline in employment from 1979 to 1986. At manufacturing employment's peak in 1979, unemployment equaled 5.8 pereent of the civilian labor force. If the nation's output increased enough to reduce the curvent unemployment rate $(7.0$ percent $)$ back to 5.8 percent, about 1.4 million jobs would result, given today's labor force. Up to one-half of these jobs would likely be in manufacturing. Even with these 
Chart 1

\section{U.S. Manufacturing Output and Employment}

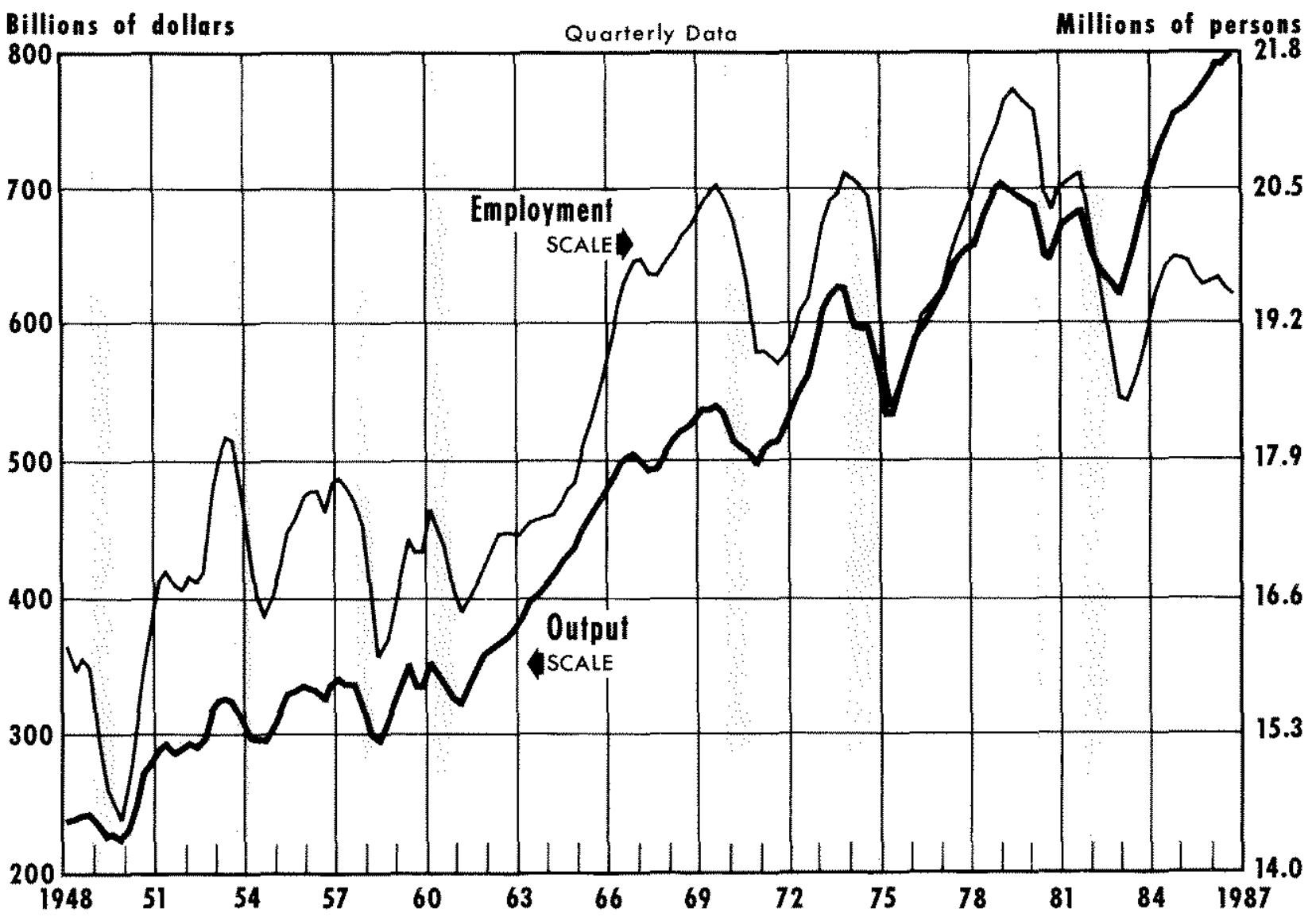

Latest data plotted: 3rd quarter 1986

additional jobs, however, manufacturing employment would remain lower than in 1979 :

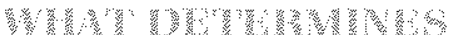

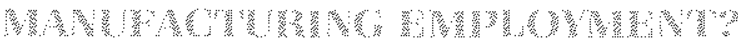

Economic theory points to several factors that in thence manufacturing emplovment. At the simplest level, fims choose their desired emplovment of labor based on a comparison of the expected cost and the expected revenue oblaned from hiring additional workers. The latter depends on both the change in output associated with emploving more lor lesst work-

${ }^{3}$ The appendix to this article further discusses the importance of cyclical movements in the decline of manufacturing employment since 1979. ess and the expected outpul price. Another way of expressing this choice is to compare the relative price of labor: the wage relative to the price of the output produced, and the productivity of addilional workers. A rise in the manulacturing wage or a fall in the price of manufactured goods mases the cost of labor relative to its productivity, reducing the incentive to employ labor. Similarly, a rise in the produclivity of workers tor a given level of employment increases the incentive to employ workers, fiven the relative cost of labor.

${ }^{4}$ The relevant productivity measure is the marginal product of labor; normally, however, output per worker, or average productivity, is the most commonly used measure. As long as the ratio of the marginal to average product of labor does not change, movements in the average product of labor will reflect the same proportional movements in the marginal product of labor 
The manufacturing sector is only one pant of the economy. Producers of manufactured products. therefore, must compete with produces in other sectors, such as agriculture, services, construction, mining, thansportation, ulilities and government, for sales and for resources, including workers. Thus, manufacturing wages and prices must be competitive in order to attract workers and sales. A simple statement of this relationship can be derived from the identical employment decisions made by firms throughout the economy. In particular, if wages equal some fraction $\left(\beta_{n k}\right.$ for manufacturing, or $\beta$ for the whole economy) of the revenue per worker in manufacturing and in the whole economy, then:

(1) $W_{\mathrm{tw}} W=\left(\beta_{\mathrm{m}} / \beta\right)\left(\mathrm{P}_{\mathrm{m}} / \mathrm{P}\right)\left(\pi_{\mathrm{tr}} / \pi\right)$

where $W_{m}$ and $W$ are wages in manufacturing and in the whole economy, respectively, $P_{n 1}$ and $P$ are the prices of output in the two sectors, and $\pi_{1: 1}$ and $\pi$ are the output per worker, or productivity, in the respective sectors. Because productivity is measured as the ratios of output to the number of workers in each sector, equation 1 can be rearanged to the following:

(2) $L_{\mathrm{tz}} / L=\left(\beta_{\mathrm{m}} / \beta\right)\left(X_{\mathrm{uz}} / X\right)\left(\mathrm{P}_{\mathrm{uz}} / \mathrm{P}\right)\left(W_{\mathrm{tu}} / W\right)^{-1}$,

where $L_{11}$ is the employment in manufacturing and $L$ is total civilian employment and $X_{t a}$ and $X$ represent their respective output levels. According to equation 2 , the share of manufacturing employment $\left(L_{41} / L\right)$ depends postively on the share of manulacturing in the nation's total output $\left(X_{n, 1} / X\right)$ and the price of manufacturing output relative to prices generally $\left(\mathrm{P}_{\mathrm{r}} / \mathrm{P}\right)$, and is inversely related to wages in manufacturing relative to wages generally $\left(W_{m} / W\right)$. Relative wages, of course, depend on relative skill differences, nonpecuniary differences of jobs in manufacturing compared with the remainder of the economy, and barriers to labor movement across sectors of the economy. Differences in the relative degree of unionization of in regulation can affect the latter factor.

Manufacturing output's share in total output depends on the demand for manulacturing output com" pared with other goods. This demand is influenced by permanent or transitory movements in real income and by the relative price of manufactured product. The share of manufacturing product in total output can also be influenced by intemational tade. Lower prices for imported manufactured products could reduce both the share of domestic manufacturing pro- duction and its relative price. Similarly, a rise in the relative price of manufactured goods due to a rise in foreign domand can increase domestic manufacturing production (for export) relative to the econony's total output.

Manufacturing output's share is of interest not just because of its influence on employment; more importantly, if indicates the direct role of manufacturing in generating real income in the economy. In addition, comparisons of the employment and output shares of the manufacturing sector indicate the relative performance of productivity, or output per worker. The next section examines the employment and output shares in the manufacturing sector. Then the implications of productivity growth for prices and output are discussed. The discussion links two of the three factors influencing the employment share, according to equation 2. The third factor, relative wages, is discussed subsequently

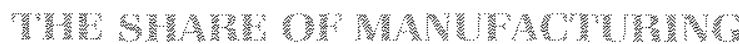

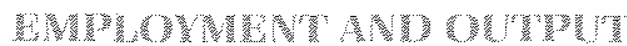

Chat 2 shows the share of manufacturing employment and output as percentages of civilian employment and real gross national product (GNP) respecm tively. The share of manufacturing output has fluctuated cyclically, but shows no trend. Employment in manufacturing has been declining as a share of total employment for a long time. The principal factor accounting for this decline has been relatively more rapid growth in labor productivity in manufacturing than in the remainder of the economy.

Chart 3 shows the ratio of labor productivity in manufacturing to that for the business sector as a whole. Labot productivity is measumed by output per worker. From 1948 to 1960, there was little difference in the growth rates of productivity in manufacturing and elsewhere, so the relative productivity level shown in the chant changed little. Note that in chart 2 , the share of labor employment in manutacturing also changed litle over this period. Since then, productivity has grown faster in the manufacturing sector, so that between 1960 and 1985, labor productivity in manufacturing increased almost 50 percent more in the manufacturing sector than in the business sector. As chart 2 shows, this rise in productivity was associated with a decline in the share of labor employment rather than a rise in the share of manufacturing output. 
Chart 2

Share of Employment and Output in Manufacturing

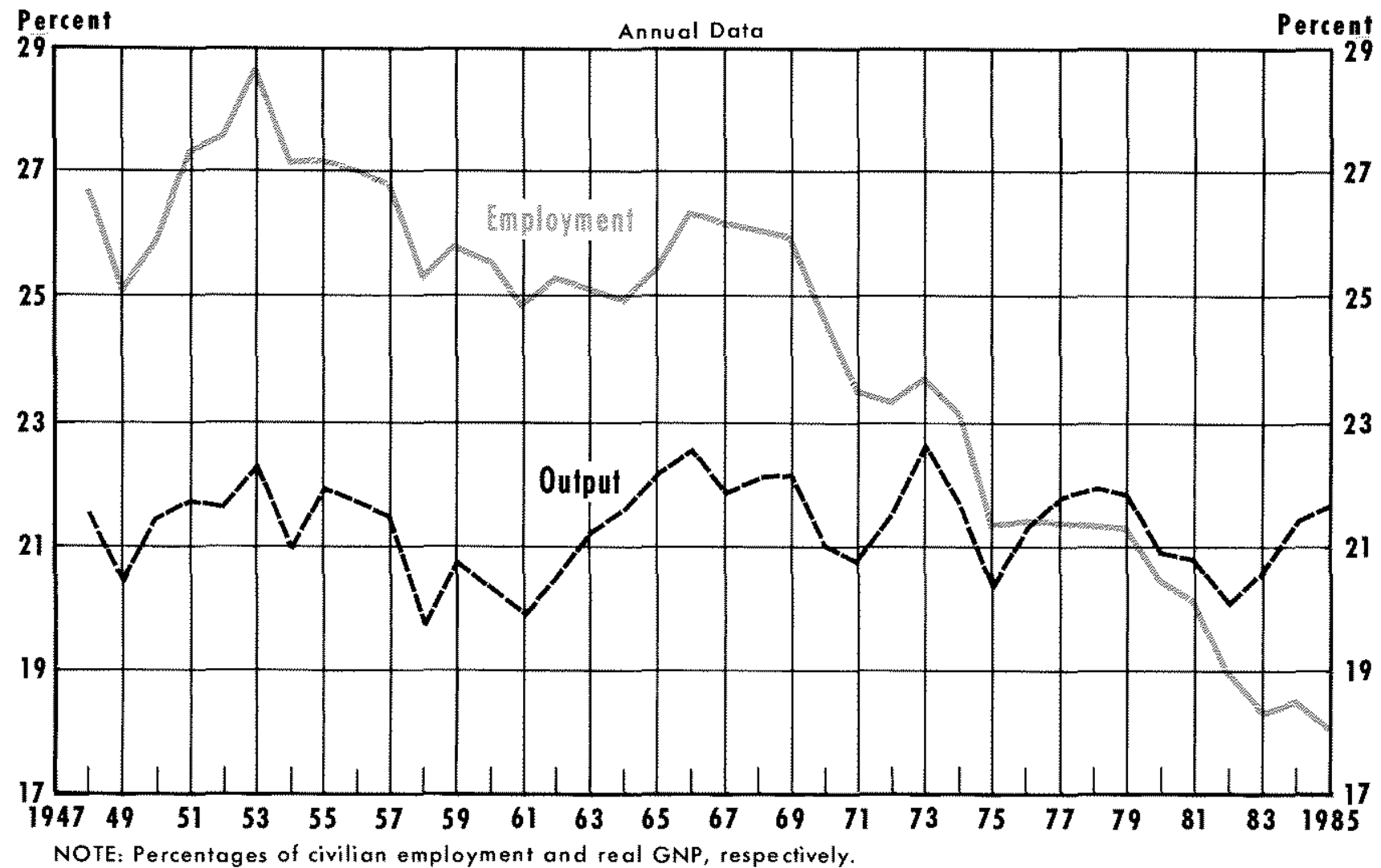

NOTE: Percentages of civilian employment and real GNP, respectively.

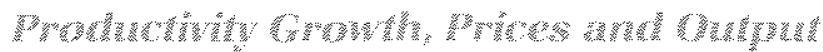

Why have productivity gains in manufacturing resulted in a relative decline in employment rather than a rise in the share of output? A simple perspective on this question is to examine the effect of productivity growth in a supply-demand framework. In figure 1, the initial supply curve and demand eurves are labeled $S$ and $D$, respectively. Given other factors that influence supply or demand decisions, the curves indicate that as the price of manufactured product rises, the quantity supplied rises and the quantity demanded falls. At the initial equilibrium price, $P_{t,}$ producers desire to produce and sell exactly the quantity of product that buyers wish to purchase.

A gain in output per worker, of productivity, raises the quantity that producers could profitably produce, given factor and product prices. Such a gain shifts the supply curve to the right, as shown in the shift from $S$ to $S^{\prime}$ in the figure. The shift in the supply results in an excess supply. Buyers are unwilling to purchase more, given the price, $P_{0,}$ and the other factors influencing demand. Thus, the product price falls as producers compete to enlarge their sales. At a new equilibrium price, $P_{1}$ in the figure, buyers purchase more and sellers are selling exactly the output they

"Productivity growth in manulacturing also has a significant effect on real GNP since this sector accounts for more than 20 percent of real GNP. For example, a 10 percent increase in output per worker would tend to increase real GNP by (0.2) (0.1) or 2 percent, other things the same. This change in real GNP would raise the demand for all normal goods and services. This shift is omitted in the figure. The initial excess supply created by a productivity improvement in manufacturing is reduced somewhat by this shift, as is the associated decline in price. 


\section{Chart 3}

\section{Relative Productivity in Manufacturing}

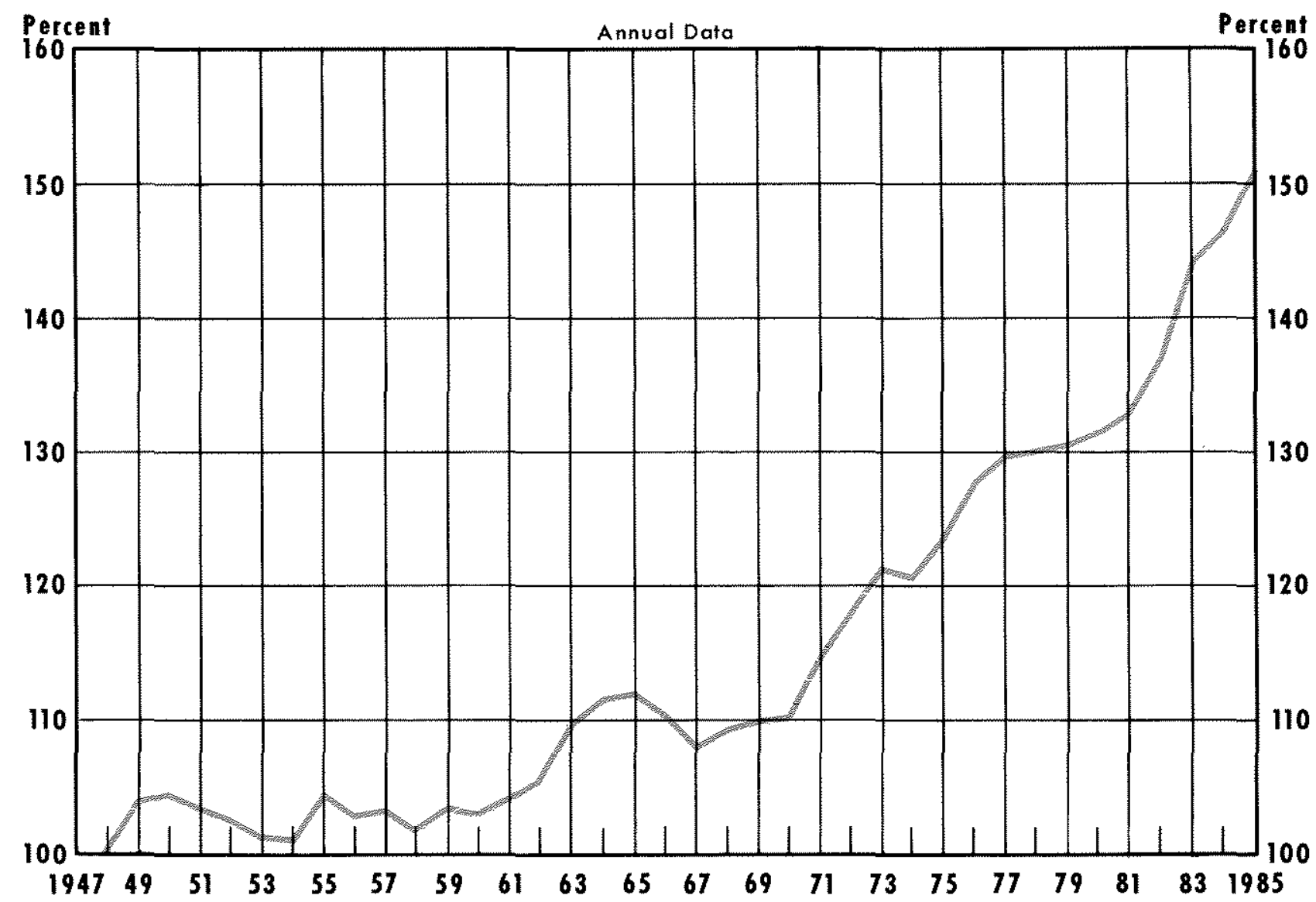

profitably choose to sell along the new supply cuve $S^{\prime}$. Thus, productivity growth increases output only to the extent that buyers are willing to increase their purchases; this willingness is influenced by the responsiveness of demand to a decline in the price of the product.

The effect of productivity growth on the size of the output increase in an industry is determined by purchasers of the product, not by the producers. If demand is quite responsive to price, then price falls relatively less and the quantity purchased rises relar tively more. Economists refer to this responsiveness as the "own price elasticity of demand"; it measures the percentage change in quantity demanded induced by a given percentage change in price. If the elasticity equals one, a given percentage-point decline in price induces an equal percentage rise in the quantity demanded. If the elasticity exceeds one, the product is said to have elastic demand; a given percentage decline in price induces a larger percentage rise in quantity demanded. If the own price elasticity of demand is less than one, demand is said to be inelastic, indicating a lower degree of responsiveness of demand to price changes.

An important implication of the magnitude of the demand response to a price change is the effect of a supply shift on total spending on the product. When supply shifts from $S$ to $S$ in the figure, the product of price times quantity, or total spending on the product, can change. If demand is elastic, the percentage rise in 
quantify demanded will exceed the percentage dew cline in price that caused it; as a result, total spending $\left(P, X_{1}\right)$ will rise $\left(P_{1} X_{1}\right.$ exceeds $\left.P_{n} X_{v}\right)$. If demand is unit elastic, total spending will not change. If demand is inelastic, the price will fall relatively more than quantity demanded rises and total spending falls.

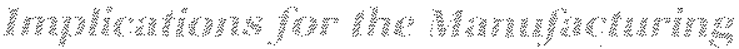 was?}

The estimated demand for manufacturing output shown in the appendix has a price elasticity that is less than one, or inelastic. Thus, according to equation 2, faster productivity growth in manufacturing has resulted in a declining share of employment because relative price reductions have more than offset the price-induced gains in output."

Relatively faster productivity growth in manufactur" ing also has reduced the share of nominal income genemted in manufacturing products. In effect, the gain in the nation's income and output occasioned by productivity growth in manufacturing has been realized in increased output elsewhere. To the extent that consumers of manufactured and other products are unwilling to buy the increased manufacturing output, resources that are saved by productivity improvement are moved into other activities to produce goods on services. The rise in the price of nonmanulactured product relative to prices of manufactured goods reflects this shift. Moreover, the share of income spent on the manutactured product declines, or the share of income spent on other products rises."

The relative price of the manufactured product is shown in chat 4 ; it is the ratio of the implicit price deflator for manufacturing output to that for business sector output, where the price indexes are set 101 in 1982. The share of nominal GNP originating in domes-

\footnotetext{
GThe price elasticity is not the only factor that iniluences the share of spending on manufacturing output. The "income elasticity," the senstivity of demand to real income changes, is also an important determinant of the share of such output and spending in a growing economy. As real income expands, the demand for all goods and services normally rises, given unchanged prices. But if the income elasticity of demand for mantractured product is less than one, then the share of manufacturing output in total output would tall given unchanged product prices. This elasticity, with respect to permanent income, is estimated to be less than one in the appendix. Transitory or cyclical changes in income have much larger effects.
}

${ }^{7}$ The agricultural sector is a mote well-known area in which productivity gains have given rise to sharp increases in the nation's real income, despite a declining share of income being spent on the product and relatively large flows of resources out of the sector.

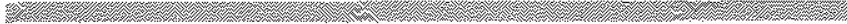

Figure

\section{The Supply and Demand for Manufacturing Output}

Price of manufocturitig output

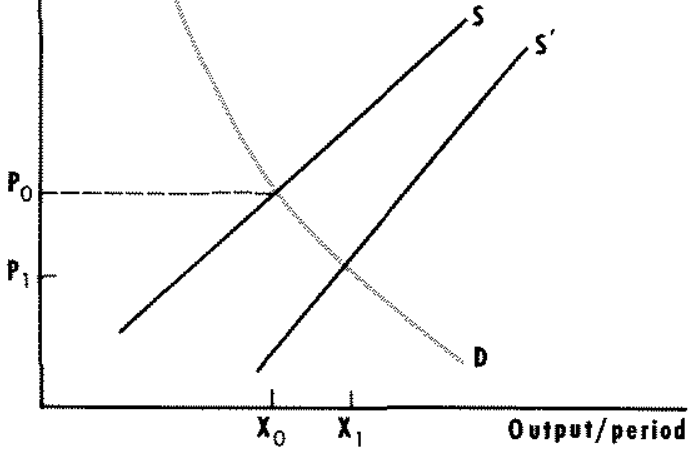

tic manufacturing is also shown in chart 4 . The decline in the relative price of manufacturing output since $\mathbf{1 9 6 0}$ has been quite rapid and reflects the relative gain in labor productivity in that sector." Since the proportion of output has been unchanged (chart 2), the share of income originating in or spent on manulacturing has declined in line with the falling relative price of manufactured product.

Two of the principal factors determining the share of labor employment devoted to manufacturing in equation 2 ate summarized in the nominal spending share in chart 4 . The dominant factor of the two has been the declining relative price of manufacturing output, which reflects relative productivily gains in the sector. Of course, its share of output and its relative price could both fall if the demand for manufac-

QThe sharp decline in the relative price of the manufactured product from 1971 to 1973 and subsequent recovery to its previous path may be due to errors in measurement. Darby (1974) has argued that wage and price controls in this period initially biased down price measures and artificially raised real output measures. If wage and price patterns in 1971-75 were artificially distorted by controls, the share of employment (chart 2) would not have been so flat in 197173 , nor would it have subsequently declined so sharply in 1973-75. 
Chart 4

\section{The Relative Price and Share of Nominal Income in Manufacturing}

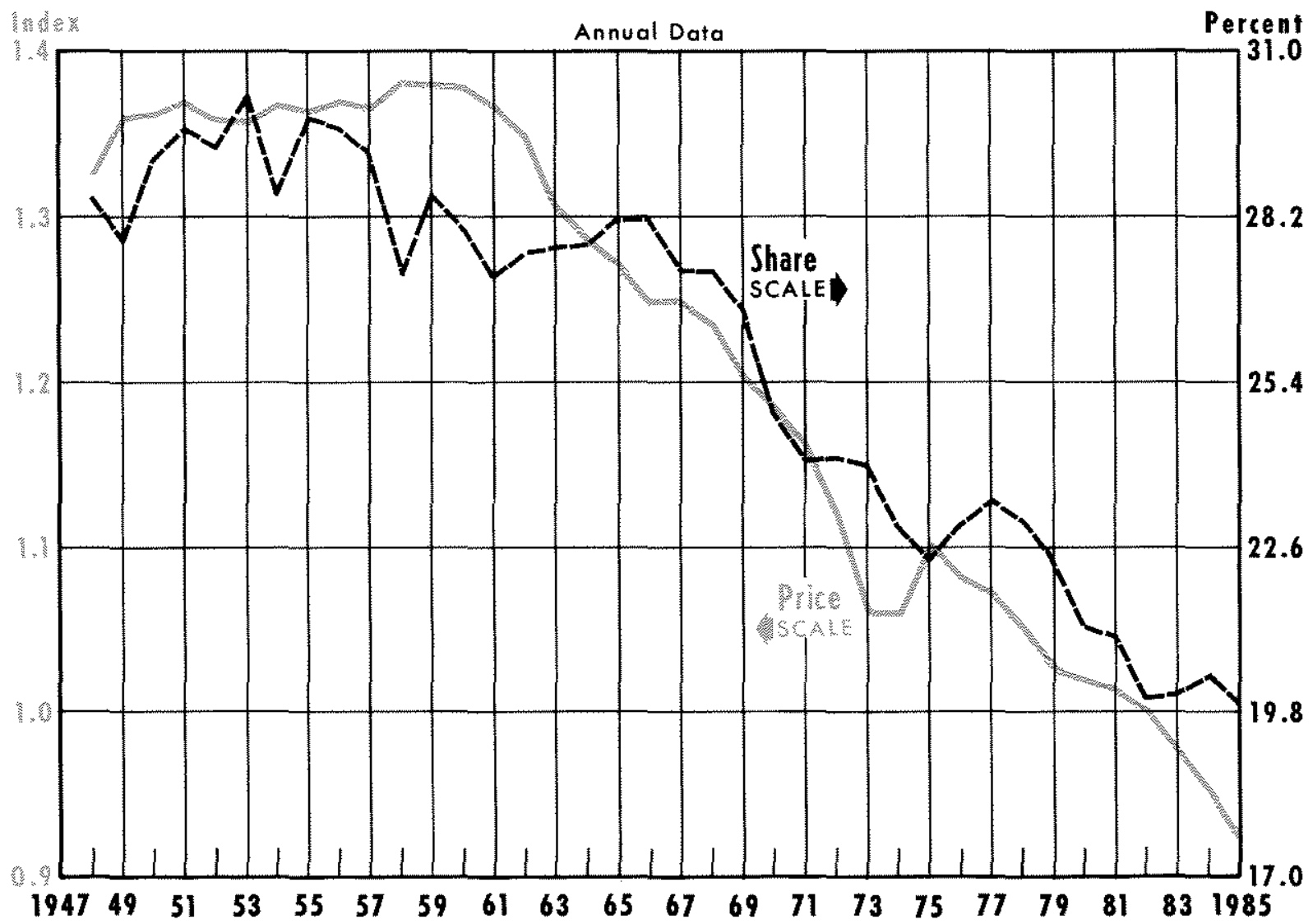

tured goods were declining. Chart 2 clearly indicates. however, that this has not been the case; the share of manufacturing output has been nearly unchanged for the past 40 years."

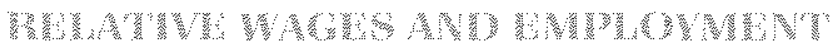

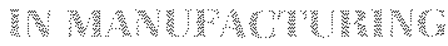

The final factor in equation 2 that influences the share of employment in manufacturing is the relative level of compensation in manufacturing. When wages

\footnotetext{
In agriculture, even the share of output has declined, making it more difficult to see the sector as an important source of expanding real income.
}

rise more (less) in one sector relative to the rest of the economy, the relative amount of employment generally is reduced (increased), given initially unchanged relative price and output levels. One way to understand this makes use of equation 1 . If relative wages in manufacturing rise, it either reflects a relative improvement in the value of manufacturing productivity for a given level of employment or will be reflected in such an improvement obtained by changing employment." In the latter case, a rise in wages relative to prices forces firms to both substitule other factots of

\footnotetext{
That is, the relative employment demand depends on relative wages. If relative wages change, there is either a movement along. or a shift in, the relative demand for labor in manufacturing.
} 
Chart 5

\section{Relative Labor Compensation in Manufacturing}

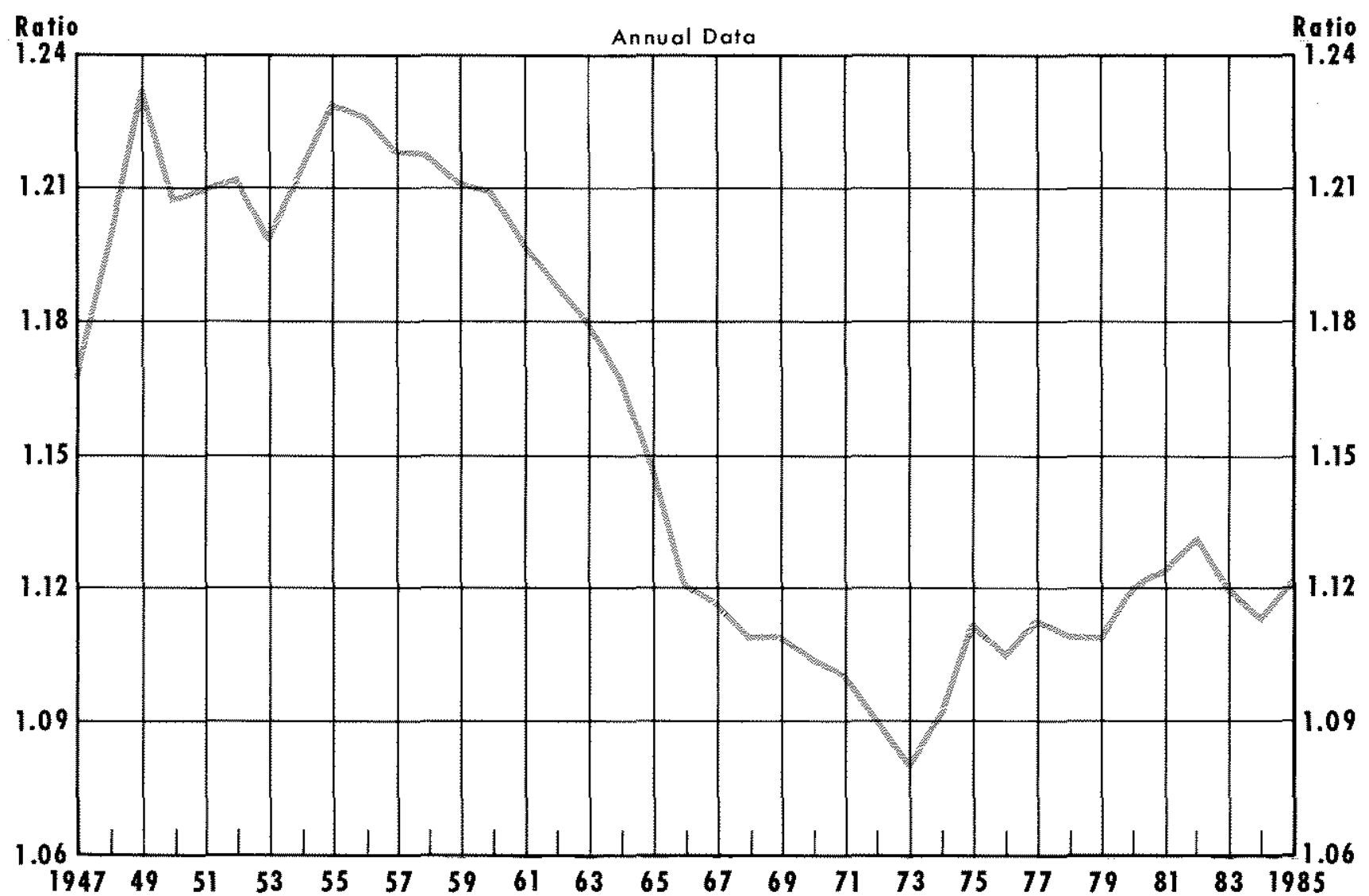

production for labor to offset some of the cost increase and to reduce production, which tends to raise product prices. Both types of adjustment raise productivity, but output declines and product prices rise when the source of the productivity gain is an increase in relative wages.

Relative wage movements have not been the dominant force in U.S. manufacturing, Gart 5 shows compensation in manufacturing relative to compensation in the business sector generally. Over the past 38 years, there has only been one major shift in the relative compensation levels that would induce a major change in relative output, price or employment patterns. From 1948 to 1960, compensation was over 20 percent higher in the manufacturing sector: This differential narrowed from 1960 to 1966 , resulting in employment growth that was quite rapid loharts 1 and
2). With the exception of that period, however, movements in relative wages do not appeat to have been large enough to have affected the share of labor employed in manufacturing significantly.

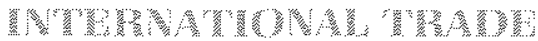

The view that foreign competition has led to relatively large losses in manutacturing employment in the 1980 s is widely held. But thete is no evidence above that the shace of domestic manufacturing lohart 2) has been depressed by the appreciation of the dollat or by increased imports." There is also no apparent

1: Fieteke (1985) has shown that there was no significant negative correlation between employment changes in domestic employment in manufacturing industries and changes in import penetration in these industries over the period 1980 to 1984 . 
evidence that relative wages in manufacturing loht 5) have been depressed in the early part of this decade due to trade-indseed reduetions in the demand for U.S. manufacturing output and employment. More carefulatention to the argumen would further ehary the analysis, however.

Domestic manulactures's compete with foreign producers. The dollar price of domestic manuantured product thenefore must be competitive with the dollar price of the foreign product. The latter price can be expressed as $\left(P_{1}^{*} / E\right)$, where $P_{m}^{*}$ is the price of the foreign product in its own currency and $E$ is the price of a dollar in mits of foreign currency. In the analysis in the figure, poductivity improvement lowems the price of domestic product; for foreign goods, this requires

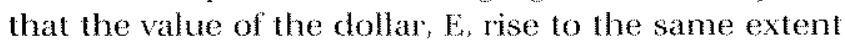
for foreign goods to remain competitive with U.S. products. In other words, productivity improvement in U.S. manufacturing, given foreign prices, tends 10 raise the value of the dollar.

Many analysts, however, emphasize the causality ruming in the opposite direction. Falling prices of foreign goods or a rise in the value of the dollar depress the clomestic prices of foreign goods. Of course, a decline in $\mathrm{P}_{n}$ due to foreign competition alone would lead to a reduction in the quantity of U.S. output supplied and increased purchases along the demand curv; the difference between L.S. purchases of manuactured products and U.S. production isupply) would be made up by imports of foreign products.

The evidence presented earlier is inconsistent with the trade hypothesis. If this hypothesis were correct the share of domestic manulacturing output in total real income would have fallen in the $1980 \mathrm{~s}$. Instead, the share has been relatively strong, especially when adjusted for the domestic business cycle." Also, if the international hypothesis were corect the growth of manufacturing output and employment abroad would have risen. Hut neither, in fact, occurred.":

12The share of manufacturing output in real GNP was 21.7 percent in 1985 and the first three quatters of 1986 . This was higher than the 1948-80 average of 21.3 percent, despite the fact that measures of transitory income losses due to unemptoyment or low capacity utilization indicate a significantly tower-than-average share would have been expected. Tatom (1986) indicates that manufacturing sector growth exceeded that predicted by income growth alone by abou 1.6 percent per year for the period $1980-85$.

See Tatom (1986). The other countries examined were Canada, Belgium, Denmark, Germany, ltaly, the Netheriands, Norway, Sweden and the United Kingdom.
Moreove: the appendix to this article shows that the exchange value of the dollar has not significantly aflected the demand for clomestic manufacturing output.

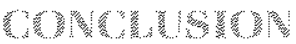

Manufacturing employment in the United States has declined slighty in ecent years, but this decline. should be assessed against a previous shaply declining trend relative to overall employment in the economy. Part of the recent decline is associated with a reduction in the relative demand for the manufacturing product due to cyclical forces in the U.S. econony. In 1979, when manutacturing employment was slightly larger, the nation's unemployment rate for civilian workers was 5.8 percent, compared with recent levels of about 7 percent. ${ }^{1+}$ Losses in income associated with cyclical increases in unemployment reduce the demand for manufacturing output rela" tively more than demand in other sectors of the econony.

But the longer-term "problem" is the strength of productivity improvement in the manufacturing sec" tor generally. Faster productivity growth in this sector has contributed significantly to real income growth in the nation; it has also contributed to a significant decline in the relative price of manufactured goods, reflecting their increased availability. While the share of manufacturing output has been maintained, its shares of employment and fotal spending have declined. This long-standing pattem has continued from 1979 to 1985 . Thus, there is no need to blame other popular villains for manufacluring employment's failure to regain its previous peak level.

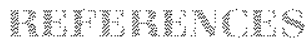

Clark, Lindtey H., ft. "Productivity's Cost: Manufacturers Grow Much More Efficient, But Employment Lags," Wall Street Jounal, December 4, 1986.

Darby, Michael R. "Price and Wage Controls: Further Evidence," in Karl Brunner and Allan Meitzer (eds.), Camegie-Rochester Conference Series, vol. 2 (Amsterdam: North Holland, 1976).

\footnotetext{
:4Te change in the unemployment rate is an accurate index of cyctical output and income losses when the "natural rate" of unemployment, the noncyclical component, is unchanged. The substantial slowing in the growth of new entrants into the labor force in the 1980 s, especially young, inexperienced people, reduced the naturai rate significantly. Of course, the latter implies that a return to a 5.8 percent rate would leave the economy with a larger percentage cycical output loss than that associated with the same unemployment rate in 1979
} 
Fieleke, Norman S. "The Foreign Trade Deticit and American In" dustry," New England Economic Review, Federal Reserve Bank of Boston (July/August 1985), pp. 43-52.

Tatom, John A. "Domestic vs. International Explanalions of Recent
U.S. Manufacturing Developments," this Review (April 1986), pp. $5-18$.

"Economic Growth and Unemployment: A Reappraisal of the Conventional View," this Review (October 1978), pp. 16-22.

\section{Appondix \\ Cychol Changes and Imployment}

Output and employment in U.S. manufacturing are strongly cvolical: transitory income changes associated with recessions or booms have a greater impact on demand for manufacturing output and the demand for labor in this sector than in the remainder of the economy. Thus, some part of the reduction in manufacturing employment from 1979, when such employment averaged 21.0 million workers, to 1986. when it averaged 19.2 million, is due to the cyclical rise in the unemployment rate over the period from 5.8 percent to 70 percent. Some simple dules of thumb allow an assessment of the curent magnitude of cyclical employment losses in manufacturing.

The first useful relationship in such an assessment is called Okun's Law, which relates cyclical movements in the unemployment rate to cyclical losses in real GNP. According to recent estimates, each percentage point of unemployment is associated with a $2 \frac{1}{4}$ percent loss in real GNP. Thus, the rise in themployment from 1979 to 1986 is associated with a loss of real GNP of about 2.7 percent, $(21 / 4)(1.2$ percent. This means that if the unemployment rate in 1986 had been 5.8 percent, nominal GNP would have been $\$ 115$ bil lion larger in the first three quarters of 1986, given prices.

To see how this gain in income would have been distributed between manufacturing and the rest of the economy, the demand for manutacturing outpul must be estimated. The demand for such output is a function of the relative price of the manufactured product

See Tatom (1978). and income; manufacturing output, however, is relatively more sensitive to thansitory fluctuations in real income than permanent changes [see Tatom (1986)].

Using potential reat GNP, XP, to measure permanent income and real GNP to measure actual real income (permanent plas transitory income), $X$, the estimated demand for annual manufacturing sector otuput, in growth ate form, for the period 1949-85 is:

$$
\begin{aligned}
& \Delta \ln X M_{8}=\begin{array}{cc}
-0.533 \Delta \ln \left(\mathrm{PM} / \mathrm{P}_{1}+2.284 \Delta \ln X_{4}-1.444 \Delta \ln \mathrm{XP}_{1}\right. \\
(-3.74)
\end{array} \\
& \overline{\mathrm{R}}^{2}=0.86 \quad \mathrm{SE}=1.35 \% \quad \mathrm{DW}=2.02
\end{aligned}
$$

where XM is manufacturing sector output, $X$ is real GNP, $(\mathrm{PM} / \mathrm{P})$ is the implicit price deflator for manufacturing output detated by the GNP deflatos and XP is potential real GNP. The constant is omited because it is not significant.

When potential and actual real GNP grow at the same rate, the demand for manufacturing output $e x$ pands at about the same rate, but cyclical fluctuations in real GNP result in much larger vartations in the demand of manufacturing output. The permanent income elasticity of demand is the sum of the actual and potential GNP coefficients, $\mathrm{O}^{2} 0.84$; the cyclical income elasticity is much larger, 2.28 . The price elasticity of demand for manufacturing output is -0.53 , or less than one. To test whether the demand for domestic manufacturing output is negatively related to the exchange value of the dollar, changes in the logarithm of the Federal Reserve Board's trade-weighted exchange rate were added to the equation. None of the coefficients above were significantly altered and the exchange rate coefficien was positive, $0.003(t=0.07)$, 
although insignificant:- According to these estimates, a 2.7 percent rise in real GNP, given prices and potential output, would result in a 6.2 percent gain in manufacturing output. Such a gain would put the share of manufacturing output at about 22.5 percent, essentially the same as at the post-World War II peak achieved in 1966 and 1973 .

Of course, a cychical gain in manufacturing output of this size would be associated with a cyclical jise in output per wokker, so that the increase in employment would be smaller than that for ouput. Equation 2 in the text and the demand equation estimate above may be used to find the manufacturing employment gain. The product ( $P \mathrm{M} / \mathrm{P})(\mathrm{Xm} / \mathrm{X})$ in equation 2 in the text is the share of nominal spending (GNP) on manufacturing product. Changes in this spending share result in proportionate changes in manufacturing employment relative to total employment.

Cyclical variations in the share of nominal GNP

When the relative price of imports is used instead of the tradeweighted exchange rate, its coefficient has the "expected" negative sign, -0.02 , but it is not statistically significant ( $t=-\quad-0.72)$. None of the elasticity estimates is significantly affected in this test ether. The relative price of imports is the ratio of the implici price deflators for imports from the National Income and Product Accounts and for the domestic manufacturing sector. originating in domestic manufacturing equal [ $\Delta \ln X \mathrm{XM}$ $-\Delta \ln X+\Delta \ln (P M / P))$; according to the demand equa tion estimate above, holding (PM/P) and XP constant, this sum is $1.284 \Delta \ln X$. For a 2.7 percent change in real GNP $\mid \Delta \ln X=2.7$ percent , the change in the nominal spending share is 3.5 percent. With an unchanged relative compensation level, equation 2 in the text and the demand function here indicate that a movement from a 7 percent to a 5.8 percent unemployment rate will result in a difference $(\Delta \ln \mathrm{LM}-\Delta \ln \mathrm{L})$ equal to 3.5 percent; since $\Delta \ln L$ is about 1.2 percent, $\Delta \ln \mathrm{L}$. is about 4.7 percent "Thus, manufacturing employment would increase from about 19.2 million workers in manufacturing to about 20.1 million, still below the 21 million level observed in 1979.

'A more direct method of estimation gives about the same conclusion. When $\Delta \mathrm{ln} L \mathrm{M}$, where LM is manufacturing emptoyment, is regressed on a constant and the current and past two quatters' growth rates of real GNP, quarterly for the period IV/1948-I/1986, the sum of the coefficients on real GNP growth yield a manufacturing employment elasticity of 1.5 , so that a 4 percent gain in manufacturing employment is associated with a 2.7 percent rise in real GNP, about the same as that indicated above.

"These calculations presume that relative wages and prices woutd be unchanged by a cyclical rise in real GNP. There is no indication, either in the charts of these variables in the text, or in correlation analysis, that these variables are cyclical. 